\title{
Implementasi Doktrin Tridarma Ekakarma Melalui Teori Perimbangan
}

\section{Kekuatan}

\author{
Faisal Rahman ${ }^{1}$ \\ faisal.ugm2010@gmail.com
}

\begin{abstract}
Abstrak
Tulisan ini menganalisis tentang implementasi Doktrin TNI yaitu Doktrin Tridarma Ekakarma (Tridek) dengan menggunakan Teori Perimbangan Kekuatan. Teori yang digunakan merupakan teori versi Barry Posen yang menggunakan tiga variabel, yaitu geografi, teknologi, dan koalisi. Teori tersebut berasumsi bahwa variabel teknologi merupakan variabel yang paling melihat ke arah luar negara dalam sebuah doktrin militer. Melalui teori Perimbangan Kekuatan, Doktrin Tridek dalam melihat ke arah luar negara memiliki berbagai kendala. Dalam variabel geografi, kendala utamanya adalah pemerintah dan TNI cenderung melihat ancaman berasal dari dalam negara. Dalam variabel teknologi, pemerintah telah melakukan berbagai upaya untuk mencapai MEF TNI yang diharapkan tercapai pada tahun 2024, namun salah satu kendala terbesarnya adalah terbatasnya anggaran yang dialokasikan oleh pemerintah untuk pemenuhan MEF TNI tersebut. Dalam variabel koalisi, salah satu kendala terbesarnya adalah masing-masing negara dalam kerja sama pertahanan, khususnya kerja sama multilateral, mempunyai agenda dan kepentingan yang berbeda dengan negara lain sehingga menyebabkan kerja sama pertahanan tersebut terhambat kemajuannya. Namun, dari berbagai upaya pemerintah dan TNI melalui Doktrin Tridek untuk melihat ke arah luar negara, variabel koalisi merupakan variabel yang mempunyai pengaruh terbesar dalam implementasi Doktrin Tridek. Hal tersebut dapat dilihat dari dilakukannya strategi hedging oleh pemerintah yang dijalankan oleh Kementerian Pertahanan dan TNI melalui diplomasi pertahanan berjalan lebih baik jika dibandingkan dengan variabel-variabel lainnya yang memiliki kendala yang rumit.
\end{abstract}

Kata kunci: Doktrin, Geografi, Koalisi, Perimbangan Kekuatan, Teknologi.

\begin{abstract}
This paper analyzes the implementation of TNI doctrine, Tridarma Ekakarma Doctrine (Tridek) by using Balance of Power Theory. Based on this theory, Barry Posen uses three determinant variables named geography, technology, and coalition. It assumes that technological is outwardly looking variable in a military doctrine. Through the theory of Balance of Power, Tridek doctrine in looking beyond the state has various constraints. In geographic variables, the main constraint is that the government and TNI tend to see threats coming from within the country. In technological variables, the government has made various efforts to achieve the TNI MEF which is expected to be achieved by 2024, but one of the biggest obstacles is the limited budget allocated by the government to the fulfillment of the TNI MEF. In the coalition's variables, one of the biggest obstacles is that each country in defense cooperation, especially multilateral cooperation, has different agendas and interests with other nations, causing such defense cooperation to hamper its progress. However, from various government and TNI efforts through Tridek doctrine to look beyond the state, coalition variables are the variables that have the greatest influence in the implementation of
\end{abstract}

1 Korespondensi: Faisal Rahman. Mahasiswa Pascasarjana Ilmu Hubungan Internasional, Gedung Nusantara II Lt.2, Fakultas Ilmu Sosial dan Ilmu Politik, Kampus Universitas Indonesia. Depok-Jawa Barat 16424. Telp. 081381380690. 
the Tridek Doctrine. This can be seen from the implementation of hedging strategies by the government run by the Ministry of Defense and TNI through defense diplomacy runs better when compared with other variables that have complex constraints.

Keywords: Balance of Power, Coalition, Doctrine, Geography, Technology.

\section{Pendahuluan}

Setiap doktrin, khususnya Doktrin Tridarma Ekakarma yang merupakan Doktrin Pertahanan Militer, mempunyai cara pandangnya tersendiri untuk mendefinisikan sesuatu sebagai sebuah ancaman atau bukan ancaman. Ancaman dapat bersumber dari luar dan dalam negara. Bentuk-bentuk ancaman dibagi menjadi tiga, yaitu ancaman militer, non-militer, dan juga hibrida yang merupakan kombinasi dari militer dan non-militer (Markas Besar Tentara Nasional Indonesia, 2010). Lingkungan strategis atau lingstra, baik itu global dan regional, sudah sepatutnya mendapat perhatian lebih bagi sebuah doktrin dalam melihat ancaman.

Kelemahan Doktrin Tridek, khususnya ketika dihadapkan dengan lingkungan strategis yang dipengaruhi oleh globalisasi, adalah dipertahankannya Sistem Pertahanan Rakyat Semesta atau Sishanrata sebagai Strategi Pertahanan Nasional. Sishanrata mengandalkan kekuatan rakyat sebagai Barisan Cadangan dalam situasi perang dengan menggunakan strategi perang gerilya. Sishanrata ini sudah menjadi Strategi Pertahanan Nasional setidaknya sejak dikeluarkannya Ketetapan Dewan Hanneg No. 85 Tahun 1947.

Penggunaan strategi tersebut dapat berarti tiga hal. Pertama, pola pikir doktrin tersebut masih dipengaruhi oleh matra darat yang tidak cocok dengan keadaan geografis Indonesia sebagai negara kepulauan. Kedua, perubahan sifat perang dalam lingkungan strategis yang mengedepankan penghancuran secara langsung objek vital tidak akan mampu diatasi oleh doktrin tersebut dengan strateginya yang mengedepankan taktik perang gerilya. Ketiga, Doktrin Militer Indonesia masih cenderung melihat ancaman berasal dari dalam negara (Prasetyono, 2002). Sementara itu, untuk dapat mencapai tujuan keamanan nasional, terutama dalam sistem internasional yang bersifat anarki ini, Indonesia sebaiknya memiliki doktrin yang cenderung melihat ancaman yang berasal dari luar negara.

Dengan doktrin yang sudah ada, penelitian ini tidak ditujukan untuk menginisiasi pembentukan sebuah doktrin baru yang berorientasi untuk melihat 
ancaman datang dari luar negara, namun lebih kepada melihat gambaran implementasi Doktrin Tridek ketika melihat ancaman datangnya dari luar negara. Terdapat beberapa teori untuk menjelaskan hal tersebut, tetapi teori yang paling tepat adalah teori Perimbangan Kekuatan. Teori ini dapat menjelaskan bagaimana sebuah doktrin melihat sebuah ancaman, dengan menggunakan sudut pandang yang outward-looking. Hal ini akan dijelaskan secara spesifik pada bagian selanjutnya. Maka dari itu, rumusan permasalahan penelitian ini adalah, "bagaimana implementasi Doktrin Tridarma Ekakarma melalui teori Perimbangan Kekuatan?”.

\section{Tinjauan Pustaka}

Terdapat beberapa tulisan yang sudah membahas mengenai implementasi doktrin pertahanan. Di antaranya adalah pembahasan mengenai doktrin militer Indonesia saat perang untuk mempertahankan kemerdekaan dari tangan Belanda (Moeimam, 2016), doktrin militer Indonesia saat transisi demokrasi (Tim Kontras, 2005 dan Honna, 1999), strategi total defense dalam keamanan nasional Indonesia (Anggoro, 2007), evolusi doktrin pertahanan Indonesia yang dibagi berdasarkan sejarah periode politik (Widjajanto, 2006), dan komparasi doktrin pertahanan Indonesia pada masa Demokrasi Terpimpin dan Orde Baru (Pinatih, 2010).

Kesimpulan dari tulisan-tulisan tersebut adalah doktrin pertahanan Indonesia juga berorientasi ke dalam, sehingga orientasi militer pun turut mengarah ke dalam negara. Hal tersebut dapat membuat intervensi langsung ke dalam masalahmasalah politik, terutama yang bersinggungan dengan ranah profesionalnya, yaitu kebijakan-kebijakan yang menyangkut tentang pertahanan negara. Kondisi tersebut setidaknya terjadi dari periode Orde Baru hingga Reformasi TNI terjadi sejak tahun 1998.

Kritik yang didapat dari tulisan-tulisan tersebut adalah kecenderungan orientasi doktrin pertahanan Indonesia untuk melihat ke dalam merupakan hal yang wajar terjadi dikarenakan sebagian besar ancaman memang berasal dari dalam dan keterlibatan militer dalam ranah politik diperlukan karena kehadiran mereka yang berlatang belakang militer sebagai pembuat kebijakan membuat kebijakan tersebut lebih tepat sasaran. Namun, setelah reformasi TNI terjadi pada tahun 2004, kebijakankebijakan pertahanan belum cenderung untuk melihat ke arah luar negara. Di saat yang 
sama lingkungan strategis berubah secara drastis misalnya ketika terjadi Tragedi 9/11 yang membuat Amerika Serikat membuat kebijakan untuk memerangi terorisme di seluruh dunia.

\section{Metode Penelitian}

Penelitian ini menggunakan metode penelitian kualitatif. Metode ini berfokus kepada fenomena-fenomena sosial melalui pengujian terhadap indikatorindikator dari teori yang sudah ditentukan (Bryman, 2008: 366). Gaya deduktif dimulai dari menjabarkan data secara umum, kemudian dikerucutkan menjadi topik apa yang akan dibahas, kemudian dilakukan pengumpulan data, intepretasi data, pemahaman secara konseptual, dan diakhiri dengan membuat kesimpulan dengan data-data yang sudah dikumpulkan sebelumnya.

Metode penelitian kualitatif dipilih karena metode ini menekankan kepada fenomena-fenomena dalam kehidupan sosial. Metode ini selaras dengan teori Perimbangan Kekuatan yang sudah ditentukan sebelumnya dan dapat menjelaskan indikator-indikator dari teori tersebut secara lebih terperinci. Gaya deduktif dipilih karena pengaplikasian teori Perimbangan Kekuatan ke dalam studi kasus yang dipilih menuntut untuk menjelaskan peristiwa secara kronologis berdasarkan pembabakan waktu yang sudah ditentukan.

\section{Hasil dan Pembahasan}

Sejarah dan perkembangan doktrin militer Indonesia dimulai sejak transisi dari pemerintahan Soekarno ke pemerintahan Soeharto. Doktrin militer pertama dalam sejarah Indonesia adalah Doktrin Tri Ubaya Çakti. Doktrin ini dibentuk pada Seminar Angkatan Darat II di Sekolah Komando Angkatan Darat (Seskoad) pada tanggal 2531 Agustus 1966 di Bandung (Widjajanto: 11). Doktrin ini menggunakan Strategi Militer Pertahanan Rakyat Semesta (Perata). Perata mengandalkan rakyat sebagai komponen cadangan yang bertugas untuk membantu angkatan militer jika terjadi perang. Strategi tersebut juga dikenal dengan istilah Total People's Defense. Pola pembinaan Perata terbagi menjadi dua yaitu Pembinaan Wilayah dan Pembinaan Teritorial (Widjajanto: 12). Pola pembinaan Perata tersebut kemudian dibagi kembali menjadi lima daerah strategis yaitu daerah wilayah musuh, daerah jalan pendekat 
strategis, daerah sasaran strategis, daerah basis strategis, dan daerah udara (Widjajanto: 12).

Tidak banyak yang dapat dibahas mengenai doktrin militer yang diprakasai oleh TNI-AD ini. Hal ini dikarenakan salah satunya tidak lama setelah seminar yang dilakukan di Seskoad, Markas Besar Hankam turut mengadakan seminar dan juga mengeluarkan doktrin militer perjuangannya yang bernama Tjatur Darma Eka Karma, yang kemudian menjadi Doktrin Induk Militer Indonesia.

Pada bulan Oktober 1966, Markas Besar Hankam mengadakan Seminar Hankam. Seminar ini kemudian menghasilkan doktrin perjuangan yang bernama Doktrin TNI Catur Darma Eka Karma (Cadek). Doktrin tersebut masih menjadikan konsep Perata sebagai strategi pertahanan utama negara. Hal tersebut juga menjelaskan bahwa doktrin pertahanan Indonesia cenderung berkonsentrasi ke dalam negara.

Salah satu hal yang terpenting dari Doktrin Cadek 1966 ini adalah disatukannya TNI dan Polri menjadi Angkatan Bersenjata Republik Indonesia (ABRI). Dapat dilihat dalam Kotama Ops tersebut jika tugas pertahanan dan keamanan negara diserahkan sepenuhnya kepada ABRI. Fungsi pertahanan yang idealnya sebagai jawaban dari ancaman yang datang dari luar dan fungsi keamanan sebagai jawaban dari ancaman yang datangnya dari dalam. Dengan demikian, ABRI merupakan aktor utama yang mendominasi sebagian besar dari implementasi strategi pertahanan dan keamanan nasional.

Pada tahun 1988, melalui Keputusan Panglima Angkatan Bersenjata No. Kep/04/II/1988, Panglima ABRI Jenderal L.B. Moerdani menetapkan Doktrin Perjuangan TNI-ABRI sebagai Doktrin Induk Angkatan Bersenjata yaitu Doktrin Catur Darma Eka Karma 1988 (Cadek 1988). Dalam Doktrin Cadek 1988, penyelenggaraan pertahanan negara terbagi menjadi tiga, yaitu sistem pertahanan, politik pertahanan, dan strategi pertahanan. Dalam doktrin ini, pertahanan dan keamanan negara masih mengedepankan Sishankamrata. Sistem pertahanan negara yang dikembangkan dengan mendayagunakan segenap sumber daya nasional dan prasarana secara menyeluruh, terpadu, dan terarah.

Doktrin Tridarma Ekakarma (Tridek) ditetapkan sebagai Doktrin Militer baru menggantikan Doktrin Cadek 1988 melalui Surat Keputusan Panglima TNI No: Kep/21/I/2007 pada tanggal 12 Januari 2007. Ditetapkannya Doktrin Tridek sebagai 
Doktrin Militer menggantikan Doktrin Cadek 1988 merupakan salah satu upaya TNI untuk mereformasi organisasinya. Salah satu hal yang menjadi fokus dalam Doktrin Tridek adalah pemisahan kembali ABRI menjadi TNI dan Polri. TNI kini berperan hanya dalam urusan pertahanan negara dan Polri mengurusi keamanan negara.

Salah satu hal yang dapat diperhatikan dari sejarah dan perkembangan doktrin militer Indonesia adalah dipertahankannya konsepsi pertahanan rakyat secara total. Mulai dari Penetapan Dewan Keamanan Negara No.35 tahun 1947 tentang Pertahanan Rakyat yang digelar di bawah satu pimpinan, yaitu TNI, hingga Doktrin Tridek yang menyatakan bahwa TNI merupakan kekuatan utama dalam sistem pertahanan negara yang bersifat semesta dan rakyat sebagai kekuatan pendukung (Mabes TNI, 2007: 6). Yang membedakan antar periode adalah istilah untuk menyebutkan konsepsi tersebut, mulai dari Perata pada tahun 1940an hingga Sishanrata pada saat ini. Namun, inti dari konsepsi tersebut tetap sama, yaitu mengerahkan rakyat sebagai kekuatan dalam Barisan Cadangan ketika diperlukan atau jika negara dalam masa konflik atau perang dengan menggelar strategi perang gerilya.

Sishanrata tersebut mempunyai beberapa kelemahan. Jika mengacu kepada Konvensi Jenewa tahun 1949, dalam situasi perang, negara yang sedang berkonflik wajib untuk membedakan mana yang angkatan bersenjata atau combatant dengan masyarakat sipil atau non-combatant. Jika TNI tetap menetapkan Sishanrata sebagai strategi pertahanan maka hal tersebut akan mengakibatkan jatuhnya korban dari rakyat sipil Indonesia karena musuh akan menetapkan rakyat Indonesia sebagai target militer yang sah karena Sishanrata tersebut. Keterlibatan rakyat dalam Sishanrata dalam situasi perang tersebut juga berlawanan dengan hasil Konvensi Jenewa yang melarang untuk melukai rakyat sipil yang 'seharusnya' tidak dilibatkan dalam situasi perang.

Kelemahan selanjutnya adalah ditetapkannya Komando Teritorial atau Koter. Pembangunan Koter pada awalnya bertujuan agar TNI harus selalu dekat dengan rakyat dan agar TNI dapat melakukan strategi perang gerilya saat perang tanpa menunggu dan menggantungkan diri pada pemerintah dan perbekalan dari Markas Besar (Kasim, 2005: 88). Dengan kata lain Koter menitikberatkan kekuatannya pada matra darat dan melakukan perlawanannya juga di darat. Hal ini tidak sejalan dengan strategi pertahanan berlapis yang digunakan oleh TNI. Eksistensi Koter dan Sinhanrata 
membuat perlawanan terjadi pada zona terakhir yaitu zona III, ketika musuh sudah mencapai wilayah Indonesia. Hal ini tentu sangat merugikan pihak Indonesia ketika berada dalam masa perang, dimana perlawanan baru digelar ketika musuh sudah mencapai lapis terakhir pertahanan Indonesia.

Kecenderungan Doktrin Tridek dalam melihat masalah ke dalam negara tidak berarti bahwa doktrin tersebut tidak sama sekali melihat ke arah luar negara. Seperti yang dikatakan oleh Posen (1984: 4) bahwa sebuah doktrin militer dapat dianalisis melalui dua teori, yaitu Teori Organisasi yang mempunyai kecenderungan untuk melihat ke dalam negara dan Teori Perimbangan Kekuatan yang mempunyai kecenderungan melihat ke luar negara.

Penelitian ini melihat bagaimana implementasi dari Doktrin Tridek melalui Teori Perimbangan Kekuatan. Doktrin Tridek yang dianalisis dalam penelitian ini adalah Doktrin Tridek versi revisi tahun 2010 melalui Lampiran Peraturan Panglima TNI Nomor Perpang/45/VI/2010 yang dikeluarkan pada tanggal 15 Juni 2010. Variabel-variabel yang menjadi alat analisis adalah variabel geografi, teknologi, dan juga perilaku koalisi. Salah satu bahasan menarik mengenai faktor geografi Indonesia adalah mengenai trinitas geografi Indonesia, yaitu geopolitik, geostrategi, dan geoekonomi.

\section{Geografi}

Pemikiran politik yang didasarkan pada aspek geografi sebuah negara lazim disebut sebagai geopolitik. Secara kebijakan, geopolitik pertama kali digunakan pada masa Kabinet Djuanda pada tahun 1957, melalui Deklarasi Djuanda yang dikeluarkan pada tanggal 13 Desember 1957 (Djalal, 1996: 136). Deklarasi Djuanda berisi (Djalal, 1996: 136-137); 1) Indonesia menyatakan diri sebagai negara kepulauan yang mempunyai corak tersendiri; 2) bahwa sejak dahulu kala kepulauan Nusantara ini merupakan satu-kesatuan; 3) ketentuan ordonansi 1939 tentang Ordonansi, dapat memecah belah keutuhan wilayah Indonesia dari deklarasi tersebut mengandung suatu tujuan; 3a) Untuk mewujudkan bentuk wilayah Negara Kesatuan Republik Indonesia yang utuh dan bulat, 3b) Untuk menentukan batas-batas wilayah Negara Kesatuan Republik Indonesia, sesuai dengan asas negara kepulauan, 3c) Untuk mengatur lalu lintas damai pelayaran yang lebih menjamin keamanan dan keselamatan Negara Kesatuan Republik Indonesia. 
Pada masa Presiden Soeharto, Deklarasi Djuanda tersebut disempurnakan. Tepatnya pada saat seminar yang diadakan oleh Kementerian Pertahanan dan Keamanan pada bulan November 1966. Pada seminar tersebut pemerintah mengeluarkan Wawasan Nusantara Bahari sebagai doktrin pertahanan dan keamanan Indonesia. Wawasan Nusantara Bahari ini berintikan pandangan Indonesia ke arah luar negara, dimana pemanfaatan dan penguasaan laut merupakan kebutuhan yang mutlak untuk meningkatkan kemakmuran dan kejayaan nasional. Wawasan Nusantara Bahari ini kemudian dimasukkan ke dalam Rencana Pembangunan Lima Tahun (Repelita) pada tahun 1972. Pada tahun 1973, sudut pandang geopolitik tersebut berkembang dari doktrin pertahanan menjadi doktrin politik (Djalal, 1996: 66).

Geostrategi hampir serupa dengan geopolitik. Geostrategi berusaha menjelaskan opsi strategis untuk memanfaatkan faktor geografi dalam pertarungan melawan berbagai ancaman. Pemahaman geografi dalam geostrategi tersebut tidak terbatas hanya pada konstruksi fisik dan peristiwa alam, tetapi juga karakter sosial di dalamnya. Geostrategi Indonesia diartikan sebagai suatu cara atau metode untuk mewujudkan cita-cita proklamasi sebagaimana tercantum dalam Pembukaan UndangUndang Dasar 1945 (Munaf dan Susanto, 2014: 54). Dengan kata lain, geopolitik merupakan studi proyek, sedangkan geostrategi adalah studi pelaksanaan (Joesoef, 2014: 34).

Menurut ahli geografi Drs. Nathaniel Daldjoeni (1991: 202), geostrategi Indonesia patut memperhatikan tujuh hal, yaitu; (1) secara demografis, Indonesia dengan penduduknya yang berjumlah lebih dari 200 juta jiwa, diapit oleh dua benua, yaitu Asia dan Australia; (2) secara ideologis, negara Pancasila kita terapit oleh negara liberalisme di selatan dan komunisme di utara; (3) secara politis, negara kita terapit oleh sistem demokratis parlementer di selatan dan sistem diktator proletariat di utara; (4) secara ekonomis, antara sistem ekonomi liberal di selatan dan sistem ekonomi terpusat di utara; (5) secara sosial, antara individualisme di selatan dan komunisme-sosialisme di utara; (6) kultural, kebudayaan Barat di selatan dan kebudayaan Timur di utara; (7) secara pertahanan dan keamanan, sistem pertahanan kontinental atau kekuatan darat di utara dan sistem pertahanan maritim di barat, selatan, dan timur.

Salah satu implementasi dari geostrategi adalah Strategi Pertahanan Berlapis yang dilakukan untuk penggelaran OMP dan OMSP. Strategi Pertahanan 
Berlapis yang digelar TNI mencakup tiga lapis, yaitu (1) lapis pertama merupakan medan pertahanan penyanggah yang berada di luar garis Zona Ekonomi Ekslusif (ZEE) dan lapisan udara di atasnya; (2) lapis kedua adalah medan pertahanan utama, yaitu dari ZEE sampai laut teritorial dan lapisan udara di atasnya; (3) lapis ketiga adalah derah perlawanan yang berada dalam wilayah kompartemen-kompartemen strategis darat, termasuk wilayah perairan nusantara dan lapisan udara di atasnya, yang dibangun atas dasar sejumlah daerah pangkal pertahanan dan perlawanan sebagai intinya.

Pemerintah Indonesia memperkenalkan gagasan Indonesia sebagai Poros Maritim Dunia pada Konferensi Tingkat Tinggi (KTT) ke-9 East Asia Summit pada tanggal 13 November 2014 (kemlu.go.id). Sama seperti halnya Wawasan Nusantara Bahari, gagasan ini turut mengedepankan faktor geografi sebagai landasan untuk berpikir dan bertindak. Ditetapkannya gagasan tersebut sebagai agenda pembangunan nasional, berlandaskan apa yang dikenal sebagai strategi trinitas, yaitu geopolitik, geostrategi, dan juga geoekonomi.

Gagasan Poros Maritim Dunia berfokus pada lima pilar, yaitu (kemlu.go.id); 1) membangun kembali budaya maritim Indonesia; 2) menjaga sumber daya laut dan menciptakan kedaulatan pangan laut dengan menempatkan nelayan sebagai pilar utama; 3) memberi prioritas pada pembangunan infrastruktur dan konektivitas maritim dengan membangun tol laut, deep seaport, logistik, industri perkapalan, dan pariwisata maritim; 4) menerapkan diplomasi maritim, melalui usulan peningkatan kerja sama di bidang maritim dan upaya menangani sumber konflik, seperti pencurian ikan, pelanggaran kedaulatan, sengketa wilayah, perompakan, dan pencemaran laut dengan penekanan bahwa laut harus menyatukan berbagai bangsa dan negara, bukan memisahkan; 5) membangun kekuatan maritim sebagai bentuk tanggung jawab menjaga keselamatan pelayaran dan keamanan maritim.

Sudah dijelaskan sebelumnya bahwa doktrin militer hingga saat ini mempunyai beberapa kelemahan, dan kelemahan tersebut berakar dari pemikiran pemerintah dan TNI yang cenderung berbasis darat. Hal tersebut diperkuat dengan total 249 operasi militer yang digelar oleh TNI dari tahun 1945 hingga 2009, sebesar $67 \%$ untuk mengatasi ancaman yang berasal dari dalam, dan hanya sekitar 30\% mengatasi ancaman dari luar negara (Widjajanto, 2013). Hal tersebut ditambah dengan rentang waktu 1945 hingga 2004, TNI-AL hanya pernah menjalankan tiga operasi 
militer yang tergolong besar, yaitu menumpas Republik Maluku Selatan atau RMS tahun 1950; menumpas PRRI/Permesta tahun 1958-1958; dan Operasi Mandala tahun 1962 (Arif \& Kurniawan, 2017: 8). Berdasarkan pengalaman tersebut, wajar jika pemerintah dan TNI mengedepankan TNI-AD sebagai pemukul utama atas ancaman yang ada (Doktrin Tridek, 2010), dan menempatkan TNI-AL dan TNI-AU sebagai komponen pendukung (Widjajanto, 2006).

Melihat ke dalam negara oleh TNI-AL dapat dilihat dari doktrin operasionalisasi angkatan, jalesveva jaya mahe, yang mengedepankan keamanan laut, bukan pertahanan laut. Hal tersebut terlihat ketika periode 2008 hingga 2010, TNI-AL aktif menindak pelaku-pelaku illegal logging dan illegal fishing (Arif \& Kurniawan, 2017: 9). TNI-AL juga masih melihat operasi anti-perompak sebagai fokus utama. Padahal, jika merujuk pada Tap MPR no. VI dan VII tahun 2000, peran militer adalah mempertahankan negara dari ancaman luar, dan peran polisi adalah mengamankan negara dari ancaman dalam. Jika melihat pada tabel 3.1, terlihat bahwa terdapat K/L lain yang dapat diserahi tugas untuk menjaga keamanan wilayah dalam negeri, seperti Kementerian Kelautan Perikanan, Polisi Perairan, Bakamla yang didirikan pemerintah tahun 2014, dan sebagainya. Namun, TNI-AL masih terlihat enggan untuk merubah cara pandang yang inward-looking menjadi outward-looking.

\section{Teknologi}

Undang-Undang Republik Indonesia Nomor 16 Tahun 2012 tentang Industri Pertahanan Bab I Pasal I, makna dari Industri Pertahanan menyatakan, “... industri nasional yang terdiri atas badan usaha milik negara dan badan usaha milik swasta baik secara sendiri maupun berkelompok yang ditetapkan oleh pemerintah untuk sebagian atau seluruhnya menghasilkan alat peralatan pertahanan dan keamanan, jasa pemeliharaan untuk memenuhi kepentingan stategis di bidang pertahanan dan keamanan yang berlokasi di wilayah Negara Kesatuan Republik Indonesia"

Berdasarkan undang-undang tersebut, tujuan penyelenggaraan industri pertahanan diantaranya adalah; 1) mewujudkan industri pertahanan yang profesional, efektif, efisien, terintegrasi, dan inovatif; 2) mewujudkan kemandirian pemenuhan Alat Peralatan Pertahanan dan Keamanan, dan 3) meningkatkan kemampuan memproduksi Alat Peralatan Pertahanan dan Keamanan, jasa pemeliharaan yang akan digunakan 
dalam rangka membangun kekuatan pertahanan dan keamanan yang andal. Sementara itu, fungsi penyelenggaraan Industri Pertahanan adalah untuk; 1) memperkuat Industri Pertahanan; 2) mengembangkan teknologi Industri Pertahanan yang bermanfaat bagi pertahanan, keamanan, dan kepentingan masyarakat; 3) meningkatkan pertumbuhan ekonomi dan penyerapan tenaga kerja; 4) memandirikan sistem pertahanan dan keamanan negara; dan 5) membangun dan meningkatkan sumber daya manusia yang tangguh untuk mendukung pengembangan dan pemanfaatan Industri Pertahanan.

Tidak semua kebutuhan TNI-AD, TNI-AL, dan TNI-AU tersebut dapat dipenuhi oleh industri pertahanan dalam negeri, seperti PT Pindad, PT PAL, dan PT Dirgantara Indonesia sebagai pemadu utama industri pertahanan dalam negeri di Indonesia. Namun, MEF Tahap II dan Tahap III tersebut dapat tercapai secara utuh jika transfer teknologi dilakukan dengan bekerja sama dengan negara atau perusahaan lain. Hal tersebut wajar dilakukan oleh pemerintah Indonesia ketika pemenuhan MEF tidak dapat dilakukan oleh industri-industri pertahanan dalam negeri. Terlebih, industri pertahanan dalam negeri dituntut untuk selalu memperhatikan dinamika lingkungan strategis global dan regional. Maka dari itu, untuk menyeimbangkan dinamika lingkungan strategis, transfer teknologi dan transfer senjata dengan negara lain sangat perlu untuk dilakukan, demi pertahanan dan keamanan negara dan bangsa Indonesia.

Posen (1984: 237) mengatakan bahwa indikator teknologi merupakan indikator yang paling sulit untuk dijelaskan bagaimana faktor tersebut berperan dalam teori perimbangan kekuatan karena tidak mempunyai keterikatan secara langsung dengan doktrin militer. Teknologi dapat menjadi variabel yang independen dan juga dependen, tergantung bagaimana diadaptasi oleh negara yang bersangkutan. Namun menurut Posen (1984: 66-67) satu hal yang pasti dari indikator teknologi ini adalah ketika teknologi militer memiliki kecenderungan untuk menguntungkan pihak yang bertahan, maka meningkatnya kekuatan militer lawan yang cenderung ofensif tidak akan seburuk jika dibandingkan ketika teknologi militer lebih menguntungkan pihak yang ofensif. Hal tersebut terjadi karena ketika teknologi militer memberikan efek bertahan yang baik, maka hal tersebut akan mengurangi kekuatan dari pihak musuh yang cenderung ofensif dan ekspansionis (Posen, 1984: 67).

Industri pertahanan dalam negeri belum mampu untuk menjadi andalan pemerintah untuk pemenuhan kebutuhan alutsista TNI. Maka dari itu cara lain untuk 
memenuhi kebutuhan tersebut adalah dengan cara impor persenjataan. Namun, impor persenjataan yang dilakukan untuk pemenuhan kebutuhan alutsista TNI dan juga MEF TNI yang direncanakan tercapai pada tahun 2024, terancam akan gagal. Kurniawan (2016: 23) memberikan tiga alasan mengapa Indonesia diragukan untuk dapat memenuhi target mencapai MEF pada tahun 2004, yaitu 1) tidak adanya kaitan yang jelas antara tujuan politik luar negeri Indonesia dan peran yang seharusnya dijalankan oleh TNI untuk mencapai tujuan tersebut; 2) Indonesia memiliki keterbatasan institusional dalam melakukan koordinasi birokrasi di sektor pertahanan negara; 3) masalah klasik yaitu kekurangan anggaran pertahanan. Untuk memenuhi kebutuhan tersebut, Indonesia seharusnya menganggarkan 2\% dari APBN untuk mencapai MEF TNI.

\section{Koalisi}

Perlu dijelaskan sebelumnya bahwa Indonesia tidak memiliki koalisi dengan negara manapun. Indonesia hanya memiliki kerja sama pertahanan yang kurang lebih memiliki beberapa persamaan dengan koalisi. Dalam kawasan ekstra-regional, Cina merupakan salah satu negara besar yang menjalin kerja sama pertahanan dengan Indonesia. Ratifikasi yang dilakukan pada tahun 2010, salah satunya membahas mengenai pertahanan siber. Menteri Koordinator Politik, Hukum, dan Keamanan Luhut Binsar Pandjaitan mengatakan kerja sama dengan Cina dijalin dengan harapan dapat menurunkan tensi yang sedang memanas di kawasan Laut Cina Selatan (nasional.tempo.co). Kerja sama pertahanan tersebut terbukti berhasil menurunkan tensi kedua negara. Hal tersebut terbukti ketika Luhut melakukan kunjungan ke Cina tahun 2016, perwakilan kedua negara sepakat untuk menghormati kedaulatan wilayah masing-masing negara, dan memperluas kerja sama tidak hanya di bidang pertahanan, yaitu di pertanian, kelautan, dan sebagainya (nasional.tempo.co).

Kerja sama pertahanan antara Indonesia dengan negara hegemon Amerika Serikat diratifikasi pada tahun 2010. Perjanjian kerja sama pertahanan tersebut di antaranya meliputi dialog dan konsultasi bilateral mengenai masalah pertahanan dan keamanan, proyek pengembangan kapasitas keamanan maritim, dan juga kerja sama logistik dan persediaan militer (Kemhan, 2015). Namun, hubungan kerja sama pertahanan antara kedua negara tersebut sempat mengalami gangguan pada tahun 
2017, ketika Panglima TNI Gatot Nurmantyo ditolak kehadirannya di Amerika Serikat. Walaupun pihak Amerika Serikat beberapa saat setelahnya sudah secara resmi meminta maaf (thejakartapost.com).

Indonesia juga menjalin kerja sama pertahanan dengan Rusia, yang telah diratifikasi sejak tahun 2003. Kerja sama pertahanan antar kedua negara diperdalam dengan rencana ditambahkannya kerja sama intelijen pada tahun 2016, ketika delegasi pemerintah Rusia melakukan kunjungan kerja pada tahun 2016 (nasional.tempo.co). Perlu dicatatkan juga bahwa Indonesia telah menjalin kerja sama pertahanan dengan Amerika Serikat, juga dalam bidang kerja sama intelijen. Dijalinnya hubungan dengan negara-negara besar, yang beberapa dari mereka berseberangan posisi politik, seperti antara Amerika Serikat dengan Cina, Amerika Serikat dengan Rusia, membuktikan bahwa politik bebas-aktif masih dikedepankan oleh Indonesia.

Di kawasan Asia Tenggara, ASEAN menjembatani negara-negara anggotanya untuk dapat bekerja sama dalam bidang pertahanan dan keamanan dengan diadakannya ASEAN Defence Ministers' Meeting atau ADMM. ADMM hadir sebagai sarana tertinggi untuk konsultasi keamanan dan mekanisme kooperatif di ASEAN. Tujuan diadakannya ADMM adalah untuk meningkatkan rasa saling percaya antar negara anggota melalui transparansi dan keterbukaan, atau yang sering disebut juga confidence building measure atau CBM (ADMM, 2017).

Pada ADMM ke-11 tanggal 23 Oktober 2017 yang diselenggarakan di Filipina, berbagai hal dibahas dalam pertemuan tertinggi antar Menteri Pertahanan di Asia Tenggara ini. Bahasan tersebut diantaranya adalah tentang melawan gerakan ekstrimis, separatis, dan terorisme; ASEAN Defence Industry Collaboration atau ADIC; interaksi maritim - khususnya dengan negara tetangga yang berbatasan dari lauttermasuk keamanan laut dari perompak; dan bahasan tentang Declaration on the Conduct of Parties dan Code of Conduct di Laut Cina Selatan (ADMM, 2017).

Salah satu kerja sama pertahanan yang dijalin oleh Indonesia adalah kerja sama patroli maritim dengan Malaysia dan Filipina. Kerja sama pertahanan di bidang maritim merupakan sebuah isu yang penting dewasa ini karena hal tersebut menyangkut tidak hanya di bidang dimensi politik dan keamanan, tetapi juga dimensi ekonomi, baik dalam hubungan antar negara dalam kerja sama tersebut maupun bagi negara itu sendiri. Kerja sama yang dijalin oleh tiga negara tersebut mencakup wilayah 
di Laut Sulu dan Laut Sulawesi. Kedua wilayah tersebut membutuhkan perhatian lebih ketika pada tahun 2016 terjadi pembajakan kapal oleh kelompok terorisme Abu Sayyaf. Kelompok terorisme yang berbasis di Filipina Selatan tersebut melancarkan aksinya dengan menyandera kapal-kapal yang melewati kedua wilayah laut tersebut dan juga menyandera awak kapal, serta meminta tebusan terhadap negara asal kapal dan awak kapal tersebut.

Terjadinya kejahatan transnasional tersebut mencerminkan ketidakamanan wilayah laut dari Indonesia, Malaysia, dan Filipina dan ketidakamanan tersebut bersifat urgensi. Kerja sama pertahanan ketiga negara tersebut disebut Patroli Maritim Trilateral atau Trilateral Maritime Patrol. Dengan dibentuknya Patroli Maritim Trilateral tersebut, menunjukkan bahwa keamanan maritim di wilayah Laut Sulawesi di dalam wilayah Indonesia, merupakan wilayah dengan penanganan extra-ordinary measures dari setiap negara dalam kerja sama pertahanan tersebut (Kusumaningtyas, 2017: 106).

Meskipun permasalahan di wilayah Laut Sulawesi dan Laut Sulu sudah dalam mendapatkan extra-ordinary measure dengan dibentuknya Patroli Maritim Trilateral, namun tujuan utama dari kerja sama pertahanan tersebut tidak kunjung terealisasikan. Kusumaningtyas (2017: 107-109) menjelaskan beberapa penyebabnya, diantaranya adalah ketiga negara tersebut masih belum mampu untuk menerapkan model patroli gabungan yang cocok sesuai dengan prinsip ASEAN Way yang dianut oleh setiap negara anggota ASEAN, termasuk Indonesia, Malaysia, dan Filipina. Alasan kedua adalah belum tuntasnya pembahasan mengenai aturan mekanisme dan wilayah patroli pelaksanaan kerja sama antara ketiga negara tersebut. Alasan terakhir adalah adanya perbedaan kepentingan nasional antara ketiga negara tersebut. Berbeda dengan Indonesia yang melihat wilayah tersebut dalam status darurat, 'kedaruratan' yang dipandang oleh Malaysia dan Filipina tidak sama. Malaysia bahkan cenderung diuntungkan dengan kerja sama pertahanan tersebut, karena hal tersebut dapat mengalihkan perhatian Filipina dari kasus sengketa mereka atas wilayah Sabah (Kusumaningtyas, 2017: 109).

Posen (1984: 59) mengatakan bahwa jika potensi ancaman dianggap semakin membahayakan dan kemungkinan perang menjadi semakin nyata, maka perilaku koalisi akan muncul. Sudah dikatakan sebelumnya bahwa pencapaian MEF 
diprediksi tidak akan tercapai pada tahun 2024. Maka dari itu, pemerintah menyiasatinya dengan diplomasi pertahanan sebagai pertahanan terdepan. Diplomasi pertahanan yang dilakukan oleh Indonesia menjalankan dua agenda strategi hedging, yaitu keterlibatan strategis dan modernisasi militer (Gindarsah, 2015: 1). Keterlibatan strategis menjelaskan bahwa Indonesia membangun kerja sama pertahanan dengan negara-negara besar seperti yang sudah dijelaskan sebelumnya, dan modernisasi militer didapatkan dari kerja sama pertahanan terlebih yang melibatkan industri pertahanan dalam negeri masing-masing negara. Diplomasi pertahanan tersebut memfokuskan kepada tiga agenda utama, confidence-building measure, memanfaatkan kapabilitas militer, dan juga meningkatkan basis industri pertahanan dalam negeri (Gindarsah, 2017: 4).

Gindarsah (2017: 6) mengatakan bahwa Indonesia mengadopsi strategi hedging untuk menghindari situasi dimana pemerintah harus memutuskan untuk memilih salah satu dari negara besar dan meninggalkan negara besar lainnya. Strategi ini selaras dengan politik bebas-aktif yang diterapkan oleh pemerintah Indonesia. Hal tersebut dapat dilihat dari 10 negara yang paling banyak menjalin kerja sama pertahanan dengan Indonesia adalah negara yang dianggap sebagai mitra kerja sama pertahanan yang krusial dan di saat yang sama juga dianggap sebagai berpotensi sebagai lawan di kemudian hari. Kesepuluh negara tersebut berdasarkan peringkat adalah Amerika Serikat, Australia, Singapura, Malaysia, Cina, Thailand, Jepang, Korea Selatan, Rusia, Prancis, Brunei, dan Turki (Gindarsah, 2017: 6).

\section{Kesimpulan}

Berdasarkan penjelasan yang ditunjukkan di atas, terlihat bahwa Doktrin Tridek masih belum maksimal untuk melihat ke arah luar negara. Kecenderungan untuk melihat ke arah dalam negara, melalui variabel-variabel tersebut, masih sangat dominan. Bahkan, ketika seorang berpangkat tinggi di TNI-AL ditanyakan tentang proses memformulasikan Poros Maritim Dunia apakah memfokuskan pada cara pandang yang outward-looking dan menggelar kekuatan berdasarkan strategi maritim, jawabannya adalah tidak (Arif \& Kurniawan, 2017: 12). Namun, kembali lagi ke konklusi sebelumnya, bahwa Doktrin Tridek tidak secara penuh melihat ke arah dalam negara. Posen melalui teori Perimbangan Kekuatan berasumsi bahwa variabel teknologi dalam sebuah doktrin militer merupakan variabel yang paling outward-looking. 
Kesimpulan dari penelitian ini adalah teori Perimbangan Kekuatan dapat 'memaksa' Doktrin Tridek yang cenderung untuk melihat ke arah dalam negara, untuk dapat melihat ke arah luar negara. Melalui masing-masing variabel tersebut terlihat kendala-kendala yang masih dimiliki oleh Doktrin Tridek. Variabel geografi dengan kendala masih enggannya pemangku kepentingan untuk melihat ke arah luar negara, termasuk TNI-AL. Variabel teknologi dengsan kendala klasik yaitu kekurangan anggaran pertahanan yang dialokasikan kepada pemerintah, yang berakibat semakin sulitnya untuk mencapai MEF yang direncanakan terpenuhi pada tahun 2024. Variabel koalisi dengan kendala Indonesia tidak mempunyai koalisi dengan negara manapun, yang dilakukan Indonesia adalah kerja sama pertahanan secara bilateral dan juga multilateral. Namun, kerja sama pertahanan tersebut merupakan bagian dari dalam Doktrin Tridek yang implementasinya paling melihat ke arah luar negara jika dibandingkan dengan variabel-variabel lain dalam teori Perimbangan Kekuatan.

\section{Referensi}

\section{Buku:}

Daldjoeni, Drs. N (1991). Dasar-Dasar Geografi Politik. Bandung: Citra Aditya Bakti.

Djalal, Dino Patti (1996). The Geopolitics of Indonesia's Maritime Territorial Policy. Jakarta: CSIS.

Joesoef, Daoed (2014). Studi Strategi: Logika Ketahanan dan Pembangunan Nasional. Jakarta: Penerbit Buku Kompas

Karim, Silmy (2014). Membangun Kemandirian Industri Pertahanan Indonesia. Jakarta: Kepustakaan Populer Gramedia.

Munaf, Dicky R. \& Susanto (2014). Geopolitik dan Geostrategi: Keamanan dan Kedaulatan Laut. Jakarta: Gramedia Pustaka Utama.

Posen, Barry R. (1984). The Sources of Military Doctrine: France, Britain, and Germany Between The World Wars. London: Cornell University Press.

Sulisningtyas, Tri dan Dicky R. Munaf (2015). Sinergitas Paradigma Lintas Sektor di Bidang Keamanan dan Keselamatan Laut. Jakarta: PT Gramedia Pustaka Utama. 


\section{Tesis:}

Kasim, Yandry Kurniawan (2005). Strategi Pertahanan Indonesia Berdasarkan Dinamika Lingkungan Strategis dan Ancaman Internal-Eksternal Tahun 1998-2004. Tesis di Program Pascasarjana Ilmu Hubungan Internasional, Fakultas Ilmu Sosial dan Ilmu Politik, Universitas Indonesia Kusumaningtyas, Annisa Sathila (2017). Kerja Sama Patroli Maritim Trilateral (Trilateral Maritime Patrol) antara Indonesia, Malaysia, dan Filipina Dalam Menindak Kejahatan di Laut Sulu dan Sulawesi. Tesis di Program Pascasarjana Ilmu Hubungan Internasional, Fakultas Ilmu Sosial dan Ilmu Politik, Universitas Indonesia.

\section{Artikel dan Jurnal:}

Anggoro, Kusnanto (2007). Unravelling total defense: territorial structure, democracy, and non-military defense. Jakarta: Center for Strategic and International Studies.

Arif, Muhammad \& Yandry Kurniawan (2017). Strategic Culture and Indonesia Maritime Security. Asia \& The Pacific Policy Studies.

Gindarsah, Iis and Adhi Priamarizki. Indonesia's Maritime Doctrine and Security Concerns. Policy Report from S. Rajaratnam School of International Studies.

Kurniawan, Yandry (2016). "Visi Poros Maritim Dunia: Proyeksi Indonesia Sebagai Kekuatan Regional?”. Jurnal Legislasi Pertahanan. Vol. 6 No. 2, Desember 2016.

Laksmana, Evan A. (2011) “The enduring strategic trinity: explaining Indonesia's geopolitical architecture", Journal of the Indian Ocean Region, 7:1 (2014). Indonesia's Strategic Thinking: Breaking Out of Its Shell?. Canberra: Council for Security Cooperation in the Asia Pacific.

(2017). "Pragmatic Equidistance: How Indonesia Manages Its Great Power Relations. New York: New York University Press.

Sukma, Rizal. Indonesia's Security Outlook, Defence Policy and Regional Cooperation, Chapter 2 in Asia Pacific Countries' Security Outlook and 
Its Implications for the Defense Sector (2010). The National Institute for Defence Studies Joint Research Series No. 5. (1997). Indonesia's Bebas-Aktif Foreign Policy and the Security Agreement' with Australia. Australian Journal of Internasional Affairs, Vol. 51, No. 2. Tim Kontras (2005) Politik Militer Dalam Transisi Demokrasi Indonesia. Jakarta: Kontras. Widjajanto, Andi (2006) Evolusi Doktrin Pertahanan Indonesia, dalam Ikrar Nusa Bhakti, et al Kaji Ulang Pertahanan: Pendekatan Substantif. Jakarta: LIPI.

\section{Makalah dan Kuliah Umum:}

Edy Prasetyono dalam Workshop Strategic Defence Review, Departemen Pertahanan, 16-17 Desember 2002.

Kusnanto Anggoro (2013) "Keamanan Nasional, Pertahanan Negara, dan Ketertiban Umum" makalah dipresentasikan dalam Seminar Pembangunan Hukum Nasional VIII oleh Badan Pembina Hukum Nasional tanggal 15 Juli 2013 di Denpasar, Bali.

Kusnanto Anggoro sebagai pemakalah pembanding dalam Seminar Pembangunan Hukum Nasional VIII, diselenggarakan oleh Badan Pembinaan Hukum Nasional, Departemen Kehakiman dan HAM RI, 14 Juli 2003

Panel oleh Arief Havas Oegroseno mengenai A Discussion on Blind Spots, Stress Points, and Potential Pitfalls in Indonesian Foreign Policy dalam Conference on Indonesian Foreign Policy 2017 di Jakarta pada tanggal 21 Oktober 2017.

\section{Artikel Daring:}

Caffrey, Craig (2017). Revised Indonesian budget brings modest increase. Jane's 360.

Diakses September 2017, pada

http://www.janes.com/article/72232/revised-indonesian-budget-

brings-modest-increase

Kemenlu RI (2014). Presiden Jokowi Deklarasikan Indonesia Sebagai Poros Maritim Dunia. Kementerian Luar Negeri Republik Indonesia. Diakses September 2017, pada kemlu.go.id/id/berita/siaran-pers/Pages/Presiden-JokowiDeklarasikan-Indonesia-Sebagai-Poros-Maritim-Dunia.aspx 
Ilyas Istianur Praditya (2017). Ini Produk Militer Terlaris Buatan Pindad. PT Pindad (persero). Diakses November 2017, pada https://www.pindad.com/ini-produk-militer-terlaris-buatan-pindad

Ahmad Fikri (2016). Jusuf Kalla Pesan 50 Panser Badak Buatan Pindad. Tempo.co. Diakses November 2017, pada https://nasional.tempo.co/read/737960/jusuf-kalla-pesan-50-panserbadak-buatan-pindad

\section{Undang-Undang dan Peraturan Pemerintah:}

Buku Putih Pertahanan Indonesia 2015

Doktrin Pertahanan Negara 2015

Doktrin Perjuangan TNI-ABRI Catur Darma Eka Karma 1988

Doktrin Penampilan TNI-ABRI Sad Daya Dwi Bakti 1994

Doktrin Tridarma Ekakarma 2010

Minimum Essential Force TNI 2015

Undang-Undang Republik Indonesia Nomor 16 Tahun 2012 tentang Industri Pertahanan Bab I Pasal I

Kebijakan Pertahanan Negara Tahun 2014

Kementerian Pertahanan Republik Indonesia, Minimun Essential Force TNI 2015

Lampiran I Perpres No. 16/2017 Tentang Kebijakan Kelautan Indonesia

Perpres No. 115/2015 Tentng Satuan Tugas Pemberantasan Penangkapan Ikan Secara Ilegal (Illegal Fishing). 